\title{
Optimization and One-Step Purification of Recombinant V Antigen Production from Yersinia pestis
}

\author{
Elahe Seyed Hosseini ${ }^{1,2} \cdot$ Mehdi Zeinoddini $^{1,2} \cdot$ Ali Reza Saeedinia $^{2} \cdot$ Valiollah Babaeipour $^{2}$
}

Published online: 2 January 2020

(c) Springer Science+Business Media, LLC, part of Springer Nature 2020

\begin{abstract}
The purpose of this study was to develop an efficient and inexpensive method for the useful production of recombinant protein $\mathrm{V}$ antigen, an important virulence factor for Yersinia pestis. To this end, the synthetic gene encoding the $\mathrm{V}$ antigen was subcloned into the downstream of the intein (INT) and chitin-binding domain (CBD) from the pTXB1 vector using specific primers. In the following, the produced new plasmid, pTX-V, was transformed into E. coli $\mathrm{ER}_{2566}$ strain, and the expression accuracy was confirmed using electrophoresis and Western blotting. In addition, the effects of medium, inducer, and temperature on the enhancement of protein production were studied using the Taguchi method. Finally, the V antigen was purified by a chitin affinity column using INT and CBD tag. The expression was induced by $0.05 \mathrm{mM}$ IPTG at $25^{\circ} \mathrm{C}$ under optimal conditions including TB medium. It was observed that the expression of the V-INT-CBD fusion protein was successfully increased to more than $40 \%$ of the total protein. The purity of $\mathrm{V}$ antigen was as high as $90 \%$. This result indicates that $\mathrm{V}$ antigen can be produced at low cost and subjected to one-step purification using a self-cleaving INT tag.
\end{abstract}

Keywords V antigen $\cdot$ Yersinia pestis $\cdot$ Intein $\cdot$ Expression $\cdot$ Purification $\cdot$ Optimization

\section{Introduction}

Yersinia pestis has evolved from gastrointestinal pathogens and its antibiotic resistance can cause a dangerous disease, i.e., plague. Therefore, plague is still considered as a major threat to human health [1-3]. The human plague vaccine (USP) is a killed whole-cell plague bacilli that prevents plague infections through subcutaneous injection [4]. However, some reports have recently demonstrated the cytotoxic effects of whole-cell vaccines and their poor protection against virulent strains without capsules $[5,6]$. The low calcium response (Lcr) of $\mathrm{V}$ antigen (LcrV) and the component 1 (F1) capsular antigen are the two important virulence factors which have been considered as vaccine candidates tested for their efficacy on humans and primates. $\mathrm{LcrV}$ is known as the virulence and multifunctional protein. This crucial protein has been shown to act at the

Mehdi Zeinoddini

zeinoddini52@mut.ac.ir

1 Faculty of Chemistry and Chemical Engineering, Malek Ashtar University of Technology, Tehran, Iran

2 Gametogenesis Research Center, Kashan University of Medical Sciences, Kashan, Iran level of secretion control by binding to other proteins in order to modulate the host immune response by altering cytokine production $[7,8]$. Genetic engineering can be used to produce recombinant vaccines using different parts of Yersinia, such as V antigen and F1 [9, 10]. To this purpose, the selection of effective methods to recombinant protein purification is a key factor of production. Highly purified recombinant proteins with the lowest and shortest time are the major problems for biotechnology researchers. Intein (INT) is the internal part of the protein that is derived from immature proteins during protein splicing process [11-13]. Since the discovery of the INT feature in 1990, this fusion tag has been used in many biotechnology applications. One of its wonderful applications is in the INT-tagged self-cleaving step to purify recombinant proteins $[14,15]$. The INT tag is separated from the target protein by thiol induction, as well as by temperature and $\mathrm{pH}$ changes for one-step protein purification. The advantage of this technique over other protein purification procedures is that the protease phase is eliminated, making the method economically affordable [16-18]. Thus, in the commercial pTXB1 and pTWIN vectors, intein is fused to the chitin-binding domain (CBD). The expressed fusion protein can be ligated to the chitin beads and then, $\mathrm{pH}$, 
temperature changes, or thiol induction leads to cleavage and separation of the target protein from INT tag and CBD. Finally, the target protein can be purified from the column without any additional amino acid $[19,20]$. On the other hand, the traditional reaction optimization method involves the influence of one variable factor at a time. This method requires costly, time-consuming, and laborious experiments. Statistical methods including Response surface and Taguchi methodologies are usually used to optimize the effective factors in increasing the production of recombinant proteins. In Response Surface method, the relationship between the independent factors and the effective response can be evaluated in designed experiments to predict, with more tests than Taguchi approach [21, 22]. In turn, in Taguchi methodology, more variables and qualitative factors can be investigated [23, 24]. Generally, when the cost and time limitations make it difficult to perform more experiments in the optimization process and also when discrete or qualitative factors such as media culture types are investigated, Taguchi design is preferred in bench-scale fermenter [25].

In this work, the INT tag was used to purify $\mathrm{V}$ antigen from $Y$. pestis in order to develop a new purification strategy for this important protein. In addition, detailed studies were conducted to find optimal conditions of temperature, medium, inducer concentrations, and overexpressed V-INT-CBD fusion protein using the Taguchi method.

\section{Materials and Methods}

\section{Primer Designing and Amplification of V Antigen}

To amplify the $\mathrm{V}$ antigen encoding sequence, specific primers were designed based on the $\mathrm{V}$ antigen gene sequence retrieved from Gene bank (Accession No. AF167310.1). The NdeI enzyme restriction site sequence was added to the forward primer (5'-GGTGGT CATATGATT AGAG CCT AC GAAC-3') and SapI enzyme restriction site sequence was also added to the reverse primer (5'-GGTGGTT GCTCT TCCGC ATTTACCAGACGTGTCATC-3'). The pET-V (pET28a containing the $\mathrm{V}$ antigen encoding sequence) was amplified using the polymerase chain reaction (PCR). The PCR mixture $(25 \mu \mathrm{l})$ contained $1 \times \mathrm{PCR}$ buffer, $4 \mathrm{mM}$ magnesium sulfate, $300 \mathrm{mM}$ of each dNTP, 40 pmol per primer, $5 \mu \mathrm{l}(1 \mathrm{ng}) \mathrm{V}$ antigen in pET28 vector, and 0.2 unit Pfu DNA polymerase (Fermentase). The amplification was performed using the Techne thermocycler, with initial denaturation at $94{ }^{\circ} \mathrm{C}$ for $4 \mathrm{~min}, 35$ cycles at $94{ }^{\circ} \mathrm{C}$ for $60 \mathrm{~s}, 30 \mathrm{~s}$ at $53{ }^{\circ} \mathrm{C}$, and $90 \mathrm{~s}$ at $72{ }^{\circ} \mathrm{C}$, and the final extension was performed at $72{ }^{\circ} \mathrm{C}$ for $10 \mathrm{~min}$. The PCR product was analyzed using $1 \%$ agarose gel electrophoresis.

\section{Cloning of V Antigen in PTXB1 Vector}

The PCR product was purified using a gel purification kit (bioneer). The PCR product and the $p T X B 1$ vector (NEB \#N6707, Biolab) were double-digested with SapI and NdeI enzymes and then ligated together with $T 4$ DNA ligase. The cloning of $\mathrm{V}$ antigen in the $\mathrm{pTXB} 1$ vector was verified by restriction enzyme mapping.

\section{The Expression and Purification of the Fusion Protein}

After confirming the pTX-V construct (Fig. 1c), the plasmid was transformed into the competent $\mathrm{ER}_{2566}$ strain of E. coli, prepared by the calcium chloride method [24]. The transformed bacteria were grown in a 1-1 Lysogeny broth (LB) containing $100 \mu \mathrm{g} / \mathrm{ml}$ ampicillin at $37{ }^{\circ} \mathrm{C}$ in an air shaker (250 rpm) until the optical density (OD600) at $600 \mathrm{~nm}$ reached $0.5-0.6$. Then, the T7 promoter was induced by $0.3 \mathrm{mM}$ isopropyl $\beta$-D-1-thiogalactopyranoside (IPTG) at $16{ }^{\circ} \mathrm{C}$ for $16 \mathrm{~h}$ (to increase the soluble protein). The expression of $\mathrm{V}$ antigen was assessed by SDS-PAGE and Western blotting at different times using specific antichitin-binding domain serum antibodies (NEB \#S6654, New England Biolabs Inc.). The cells were harvested and resuspended in $100 \mathrm{ml}$ of column buffer $(20 \mathrm{mM}$ Tris- $\mathrm{HCl}, \mathrm{pH}$ 8.0, $0.5 \mathrm{M} \mathrm{NaCl}$ ) and the crude cell extracts were prepared by sonication for 10 cycles of $30 \mathrm{~s}$ (Hielscher Ultrasonic, Germany). The supernatant was separated from the cell debris by centrifugation at $12,000 \times g$ for $30 \mathrm{~min}$ at $4{ }^{\circ} \mathrm{C}$ and passed through a $1 \times 10 \mathrm{~cm}$ column (Bio-Rad, Hercules, CA) containing $10 \mathrm{ml}$ of chitin beads (NEB \#S6651). The flow rate was $0.5 \mathrm{ml} / \mathrm{min}$. After loading the supernatant on the column, the flow rate was increased to $2 \mathrm{ml} / \mathrm{min}$, and the column was thoroughly washed with the column buffer until the eluted non-specific protein content reached a minimum. Thereafter, a column buffer containing $50 \mathrm{mM}$ dithiothreitol (DTT) was slowly passed through the column, the flow was stopped, and the column was incubated at room temperature for 16 to $40 \mathrm{~h}$. Each fraction ( $1 \mathrm{ml}$ ) containing $\mathrm{V}$ antigen was obtained by eluting the column with the column buffer. All samples were analyzed by SDS-PAGE using $12 \%$ Tris-glycine gel. The protein concentration was estimated using the Bradford method. After purification, DTT was removed from the buffer and the protein was concentrated using a Millipore centricon tube.

\section{Optimization of V Antigen Expression}

The enhancement of recombinant protein production and subsequently, the purification of the target protein, the effects 


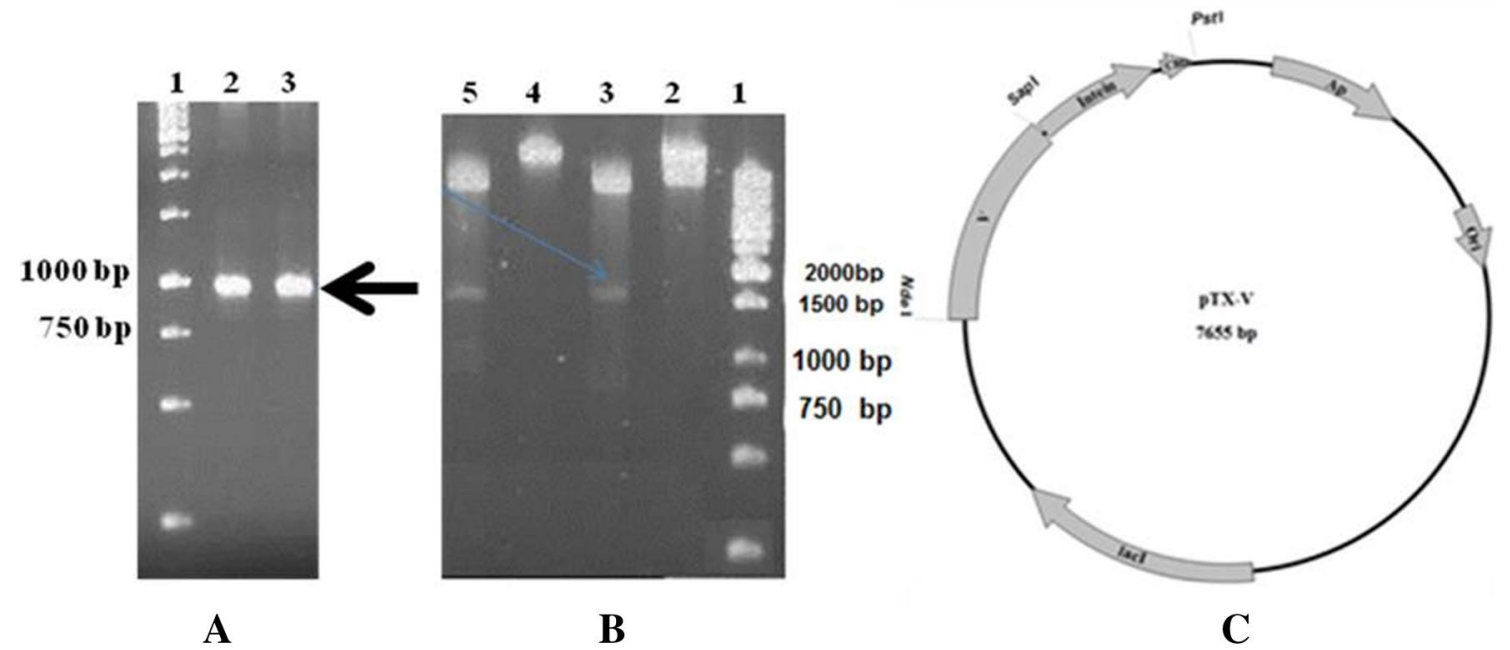

Fig. 1 a Analysis of the PCR product with specific primers, pfu enzyme and $p E T-V$ plasmid as a template. 1 -DNA Ladder $1 \mathrm{~kb}, 2$ and 3-PCR products at $60{ }^{\circ} \mathrm{C}$ and $57^{\circ} \mathrm{C}$. b Double digestion of $p T X$ -

$V$ using PstI/NdeI. 1-DNA Ladder $1 \mathrm{~kb}, 2$-undigested $p T X B 1,4-$ undigested $p T X-V, 3,5$ - double-digested $p T X-V$ in the first and second clones. $\mathbf{c}$ pTX-V constructs

Table 1 Factors and levels of study in Taguchi experiment

\begin{tabular}{llll}
\hline Culture medium & $\begin{array}{l}\text { IPTG concentra- } \\
\text { tion }(\mathrm{mM})\end{array}$ & $\begin{array}{l}\text { Induction tem- } \\
\text { perature }\left({ }^{\circ} \mathrm{C}\right)\end{array}$ & $\begin{array}{l}\text { Sur- } \\
\text { face } \\
\text { factor }\end{array}$ \\
\hline $\mathrm{TB}$ & 0.05 & 15 & 1 \\
$\mathrm{SB}$ & 0.1 & 20 & 2 \\
$32 \mathrm{Y}$ & 0.15 & 25 & 3 \\
\hline
\end{tabular}

$T B$ terrific broth (tryptone $1.2 \%$, yeast extract $2.4 \%$, glycerol $0.5 \%$ ), $S B$ Super Broth (tryptone $3 \%$, yeast extract $2 \%$, MOPS $1 \%$, Glucose $2 \%$ ), 32Y (tryptone $0.8 \%$, yeast extract $3.2 \%, \mathrm{NaCl} 0.58 \%$ in Tris$\mathrm{HCl} 10 \mathrm{mM}, \mathrm{pH} 7.6$ )

of temperature on the induction $\left(15,20\right.$, and $\left.25^{\circ} \mathrm{C}\right)$, media (Terrific Broth or TB, contains tryptone $1.2 \%$, yeast extract $2.4 \%$, and glycerol $0.5 \%$; Supper Broth or SB which contains tryptone $3 \%$, yeast extract $2 \%$, MOPS $1 \%$, and Glucose $2 \%$; and $32 \mathrm{Y}$ which contains tryptone $0.8 \%$, yeast extract $3.2 \%$, and $\mathrm{NaCl} 0.58 \%$ in $10 \mathrm{mM}$ Tris- $\mathrm{HCl}, \mathrm{pH} 7.6$ ), and inducer concentration $(0.05,0.1$ and $0.15 \mathrm{mM})$ were investigated using the Taguchi statistical method [20] (Table 1). The Taguchi method is used to evaluate the factors considered. This method allows the simultaneous study of different effective factors and their interactions. For this purpose, the experiments were designed on the L9 orthogonal array (Table 2) based on which each proposed test condition was repeated twice. Then the results (final concentration of the recombinant protein) were analyzed using Minitab-16 software. Taguchi uses analysis techniques that do not depend on a model that relates the response to the factor effects. Rather, it uses a calculated response average to identify factors and their levels that yield maximum quality or quantity
Table 2 Suggested experiments based on the Taguchi method

\begin{tabular}{llll}
\hline Factor & $\begin{array}{l}\text { Type of culture } \\
\text { medium }\end{array}$ & $\begin{array}{l}\text { Inducer concentra- } \\
\text { tion }(\mathrm{mM})\end{array}$ & $\begin{array}{l}\text { Induction } \\
\text { temperature } \\
\left({ }^{\circ} \mathrm{C}\right)\end{array}$ \\
\hline 1 & TB & 0.1 & 15 \\
2 & SB & 0.05 & 15 \\
3 & $32 \mathrm{Y}$ & 0.15 & 15 \\
4 & TB & 0.15 & 20 \\
5 & SB & 0.1 & 20 \\
6 & $32 \mathrm{Y}$ & 0.05 & 20 \\
7 & TB & 0.05 & 25 \\
8 & SB & 0.15 & 25 \\
9 & $32 \mathrm{Y}$ & 0.1 & 25 \\
\hline
\end{tabular}

of the considered response (in this research the amount of recombinant protein). To compute the average performance or mean effect of any factor, amount of recombinant protein of experiments related to any level of each parameter are added and divided by the number of such trials.

\section{Results}

\section{Genetic Construct of $p T X B 1-V$}

After the PCR reaction, the product was confirmed by the emergence of a 981 bp band on 1\% agarose gel electrophoresis at about 981 bp (Fig. 1a). To clone the $\mathrm{V}$ antigen in pTXB1, the PCR product of the previous step and pTXB1 were digested by SapI and NdeI restriction enzymes, and 
Table 3 The optimization results of cultivating conditions and induction in the production of $\mathrm{V}$ antigen based on orthogonal array

\begin{tabular}{|c|c|c|c|c|c|c|c|c|c|c|}
\hline Factor & $\begin{array}{l}\text { Induc- } \\
\text { tion } \\
\text { temp. } \\
\left({ }^{\circ} \mathrm{C}\right)\end{array}$ & Medium & IPTG (mM) & $\mathrm{OD}_{600}$ & $\begin{array}{l}\text { Dry weight } \\
(\mathrm{g} / \mathrm{l})\end{array}$ & $\begin{array}{l}\text { Total protein } \\
(\mathrm{g} / \mathrm{l})\end{array}$ & $\begin{array}{l}\text { Producing } \\
\text { time (h) }\end{array}$ & Expression (\%) & $\begin{array}{l}\text { Productivity } \\
(\mathrm{g} / \mathrm{l} / \mathrm{h})\end{array}$ & $\begin{array}{l}\text { Recombinant } \\
\text { protein }(\mathrm{g} / \mathrm{L})\end{array}$ \\
\hline 1 & 15 & TB & 0.1 & 12 & 5.25 & 3.26 & 54 & 42.5 & 0.026 & 1.38 \\
\hline 2 & 15 & SB & 0.05 & 6 & 2.76 & 1.77 & 54 & 47.8 & 0.015 & 0.83 \\
\hline 3 & 15 & $32 \mathrm{Y}$ & 0.15 & 6 & 2.76 & 1.8 & 54 & 48 & 0.015 & 0.86 \\
\hline 4 & 20 & $\mathrm{~TB}$ & 0.15 & 8 & 3.68 & 2.02 & 30 & 26.7 & 0.015 & 0.52 \\
\hline 5 & 20 & SB & 0.1 & 5 & 2.3 & 1.33 & 30 & 37.8 & 0.017 & 0.49 \\
\hline 6 & 20 & $32 \mathrm{Y}$ & 0.05 & 5 & 2.3 & 1.36 & 30 & 39.2 & 0.016 & 0.52 \\
\hline 7 & 25 & $\mathrm{~TB}$ & 0.05 & 8.5 & 3.91 & 2.61 & 24 & 49.69 & 0.05 & 1.28 \\
\hline 8 & 25 & SB & 0.15 & 7 & 3.22 & 1.96 & 24 & 40.77 & 0.03 & 0.78 \\
\hline 9 & 25 & $32 \mathrm{Y}$ & 0.1 & 8 & 3.68 & 2.02 & 24 & 26.69 & 0.02 & 0.52 \\
\hline
\end{tabular}

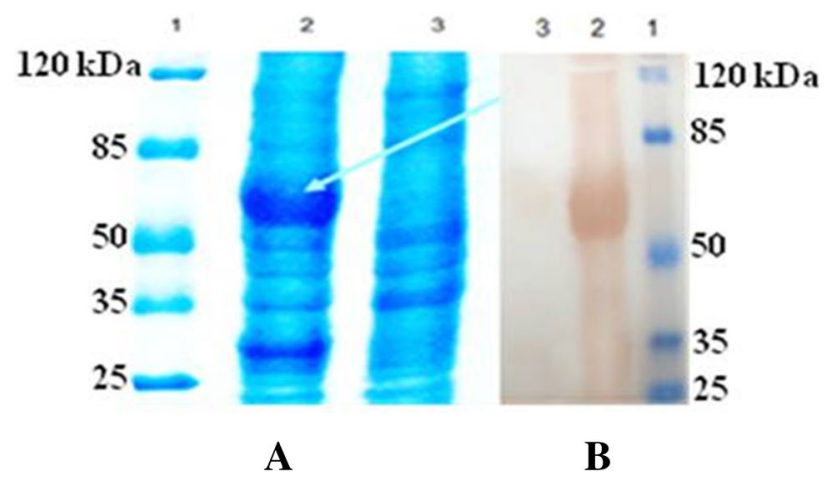

Fig. 2 Expression analysis of recombinant $\mathrm{ER}_{2566}$ harboring of $p T X-V$ using SDS-PAGE (a) and Western blot (b). (1) Protein size marker, (2) after induction and (3) before induction

the product was ligated into the pTXB1. Two colonies were randomly selected and pTXB1-V double digestion was performed using PstI and NdeI enzymes (we could not use SapI enzyme because this site was disrupted after cloning, and the restriction site of PstI is present on pTXB1 but not in the sequence of the cloned $\mathrm{V}$ antigen). According to Fig. 1b, the emergence of a 1772 bp band on 1\% agarose gel electrophoresis confirmed the production of a new plasmid pTXB1-V (Fig. 1c).

\section{The Fusion Protein (V-INT-CBD) Expression}

The pTXB1-V plasmid was transferred into E. coli ER2566 and induced by IPTG. The protein expression was assessed by using SDS-PAGE and Western blotting at 0 and $4 \mathrm{~h}$ postinduction. A protein size of about $65-\mathrm{kDa}$ confirmed the expression of $\mathrm{V}$ antigen together with INT and CBD (Fig. 2) in which the molecular weight of INT and CBD was about $34 \mathrm{kDa}$ and the molecular weight of $\mathrm{V}$ antigen was about $33 \mathrm{kDa}$.

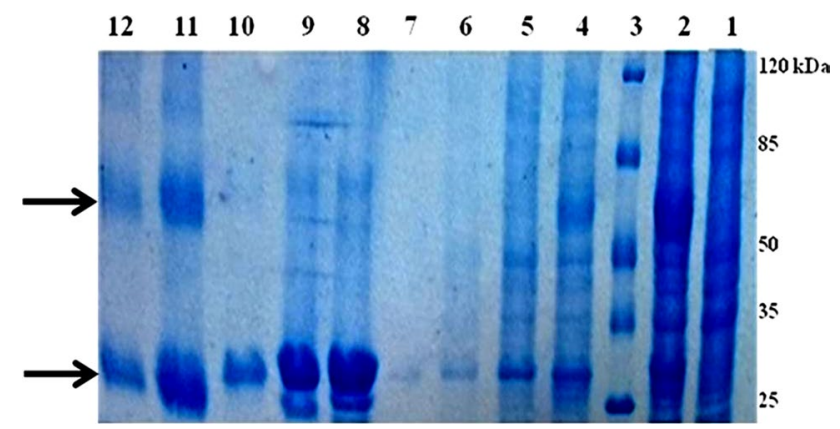

Fig. 3 Purification of $\mathrm{V}$ antigen using intein tag. Expression at zero time (1) and after four hours of induction (2), protein size marker (3), cell lysis (4), the output after passing the cell lysis from column (5), output of washing column with buffer (6), initial output after induction by cleavage buffer (7), purified protein after $40 \mathrm{~h}(8,9$, and 10$)$, the chitin beads after cleavage step (11), output after striping step (12)

\section{Purification of V Antigen}

The V-INT-CBD fusion protein was purified using chitin beads affinity chromatography. To this end, the lysed cells were passed through a column packed with chitin beads. After washing and removal of non-specific proteins, most of the fusion precursors were attached to the resin due to the high affinity of CBD to chitin beads. A lysis buffer containing $50 \mathrm{mM}$ dithiothreitol (DTT) as a cleavage disulfide bond was added into the column and incubated at room temperature for $16 \mathrm{~h}$ to release $\mathrm{V}$ antigen. In this step, INT and CBD were bound to chitin column. Finally, to remove INT-CBD from the resin, a 2\% SDS stripping buffer was flowed through, and CBD and INT (34 kDa) were eluted from the chitin resin. Figure 3 shows the purification step of $\mathrm{V}$ antigen with an INT tag on SDS-PAGE. The results of recombinant protein optimization using the Taguchi method are shown in Table 3 . Table 4 shows the analysis of variance (ANOVA) for the responses of recombinant protein production carried out according to the factors' contribution 
Table 4 Analysis of variance for the obtained results of recombinant protein optimization using Taguchi method

\begin{tabular}{lllllll}
\hline Factor & DOF (f) & Sum of Sqrs. (S) & Variance $(\mathrm{V})$ & $F$ ratio $(\mathrm{F})$ & Pur Sum $\left(\mathrm{S}^{\prime}\right)$ & Percent $P(\%)$ \\
\hline Temperature & 2 & 0.412 & 0.206 & 11.207 & 0.375 & 41.626 \\
Medium & 2 & 0.316 & 0.158 & 8.584 & 0.279 & 30.928 \\
IPTG & 2 & 0.137 & 0.137 & 3.73 & 0.1 & 11.133 \\
Others & 2 & 0.035 & 0.017 & & & 16.313 \\
\hline
\end{tabular}
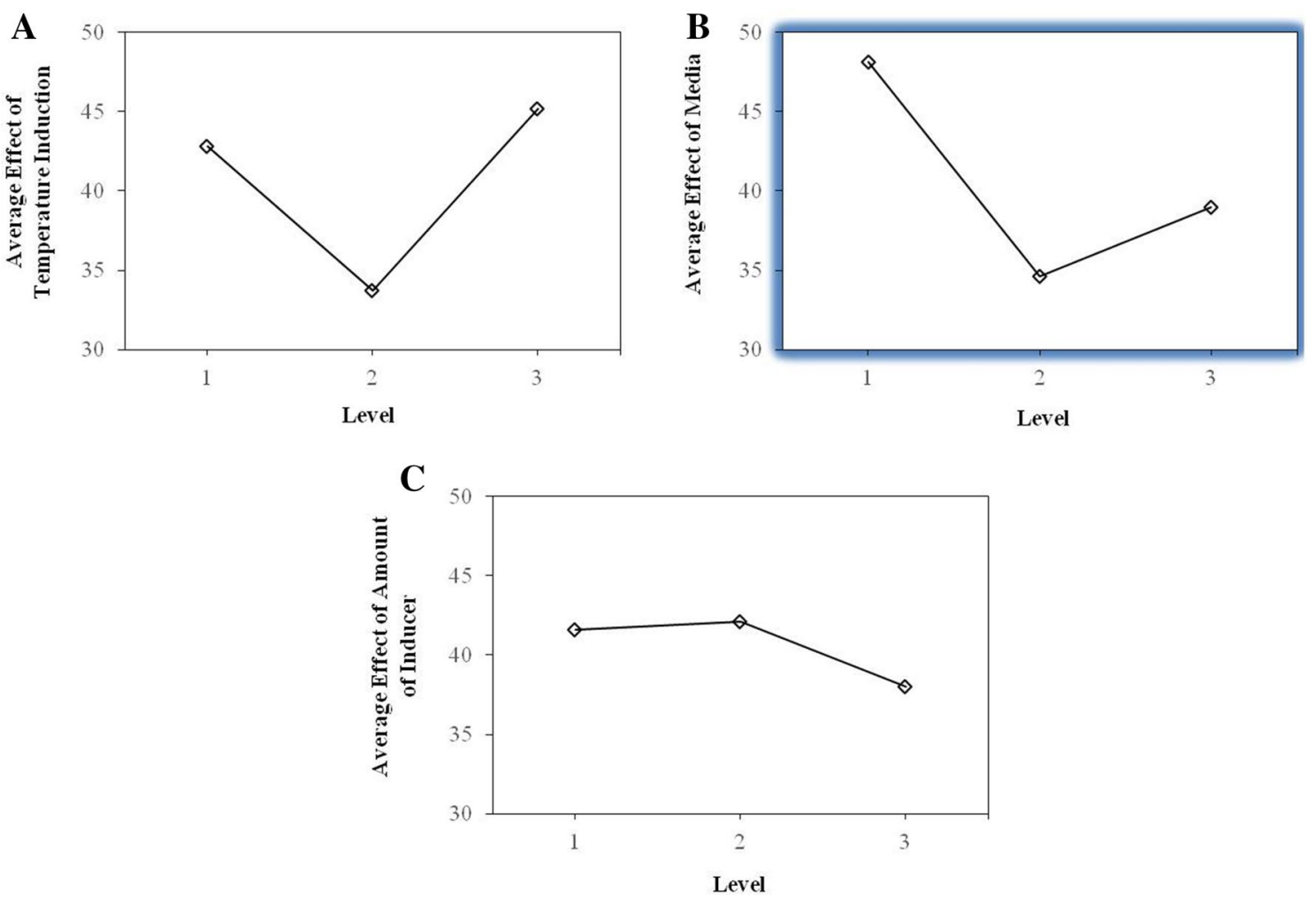

Fig. 4 The mean effect of temperature induction (a), media (b), and inducer concentration (c) at different levels on the recombinant fusion protein production. To compute the average performance or mean

by the Taguchi method. In addition, the optimal conditions were obtained by analyzing the final concentration of the recombinant fusion protein and the variance of productivity (ANOVA).

The average effect of the investigated four factors has been plotted in Fig. 4 for visual inspection. The higher the slope of the graph of each factor in these figures indicates the amount of factor effect on the amount of produced protein. Hence, it can be concluded that the type of medium had the greatest influence on the production of the recombinant fusion protein. Also, the induction temperature had the greatest effect impact on the protein production, while IPTG concentration had the least effect (Fig. 4). Furthermore, the results showed that test 7 had the optimum conditions for the production of an INT-V antigen fusion protein in E. coli. Figure 5 shows the effect of different conditions including effect of any factor, amount of recombinant protein of experiments related to any level of each parameter are added and divided by the number of such trials

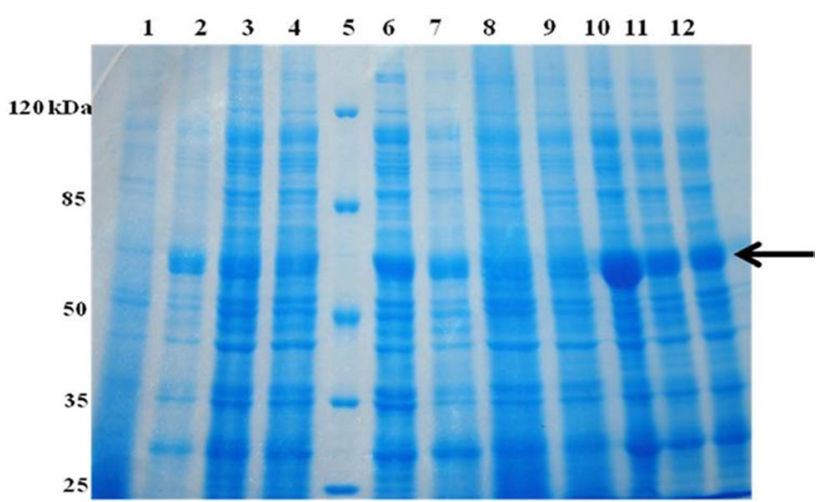

Fig. 5 Coomassie brilliant blue staining of protein, expressed in different temperatures, IPTG concentrations and culture medium by Taguchi statistical method. Time zero before induction $(1,9)$, test level one (2), two (3), three (4), protein size marker (5), test level four (6), five (7), six (8), seven (10), eight (11) and nine (12) 


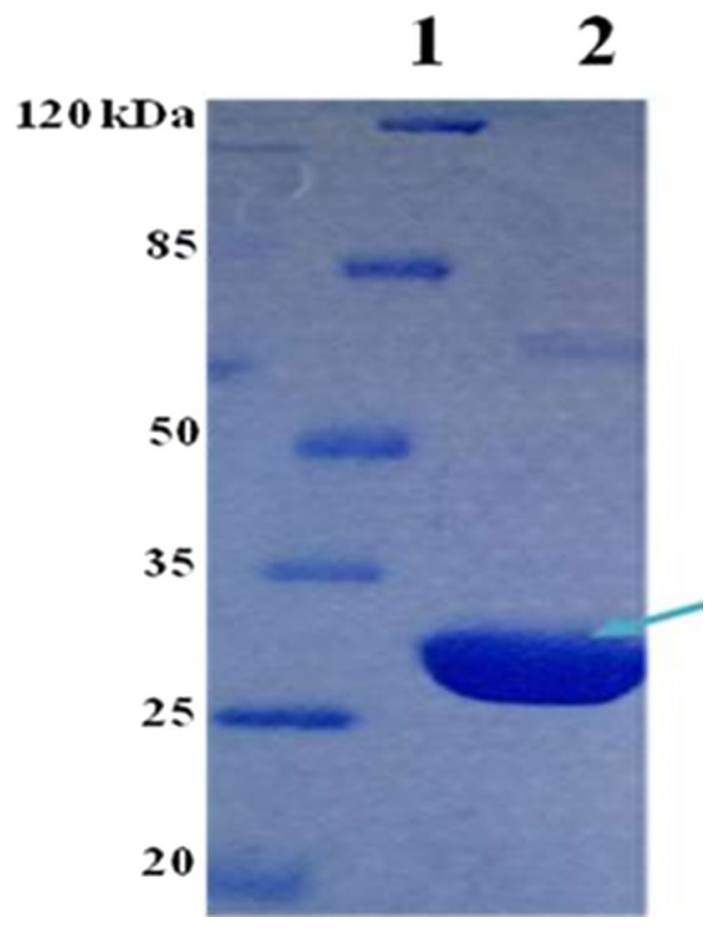

Fig. 6 Purified protein obtained from optimizing the $\mathrm{V}$ antigen production using INT after $16 \mathrm{~h}$ incubation at $4{ }^{\circ} \mathrm{C}$ in cleavage buffer. Protein size marker (1), purified protein (2)

temperature, IPTG concentration, and medium on the V antigen expression. After optimizing the production conditions, the cells were incubated in the cleavage buffer after incubation at $4{ }^{\circ} \mathrm{C}$ for $16 \mathrm{~h}$ to obtain a protein with a high purity of $90 \%$ and a suitable efficiency, as shown in Fig. 6.

\section{Discussion}

There is no safe or effective plague vaccine. The World Health Organization classifies the plague as a recurrent disease and as a class A pathogen causing an epidemic disease [26]. Killed whole-cell vaccines can only prevent pests and live attenuated vaccines, making guinea pigs and mice immune to plague, although this vaccine has health problems for humans [27, 28]. Today, researchers emphasize subunit vaccine development. For decades, humans have been focusing on two recombinant proteins, Yersinia pestis, $\mathrm{F} 1$ and $\mathrm{V}$ proteins, as vaccine candidates $[9,10]$. In order to facilitate the purification of recombinant proteins, soluble and affinity tags, such as schistosomiasis glutathione S-transferase (GST), Escherichia coli maltose-binding protein (MBP), transcription termination anti-termination factor (NusA), and peptide tags, such as poly His and poly Arg, are often used [29-32]. Since the affinity tag can affect the activity and/or structure of the target protein, it is typically cleaved from the target protein by a protease. Therefore, the isolation of protease and target protein fusion markers requires some additional purification steps [33]. In addition, proteases are generally inefficient and non-specific, resulting in partially cleaved products. In an intein (INT)-based purification system, a modified INT fusion that induces a cleavage reaction at one end is catalyzed between the chitin-binding domain (CBD) and the recombinant target protein [34]. Using the natural self-splicing mechanism of INT, genetic engineers are able to produce commercial INT vectors to obtain recombinant proteins that do not require enzymatic or cofactor removal labels [35]. The most important feature of INT tag in recombinant protein production is its self-cleavability with the addition of amino acids at the end of the target protein [36]. Furthermore, this method does not require proteases enzyme and time consuming steps for the removal of target proteins. Wood and co-authors believed that this method combined with other methods not only reduces the time and cost of recombinant protein production but also improves the efficiency of the final product $[17,37,38]$. Co-expression of $\mathrm{V}$ antigen with a suitable carrier protein results in the protease being less susceptible to degradation during purification [39]. For this purpose, different expression systems are used to increase the production of $\mathrm{V}$ antigen. V antigen with GST and INT-CBD was produced in a relatively fused form in 2000 using three expression systems and after cleavage and purification of the target protein, its final concentration was 25 (pGEX-5X-2), 31 (pGEX-6P-2), and $0.75 \mathrm{mg} / 1$ [40]. In the present study, we first cloned and optimized the expression and purification of $\mathrm{V}$ antigen in the pTXB1 vector containing the $28-\mathrm{kDa}-\mathrm{INT}$ tag and $6-\mathrm{kDa}-\mathrm{CBD}$. $\mathrm{V}$ antigen production was examined using the INT tag to assess the self-cleavage properties of INT and to optimize culture conditions to increase protein production. The results of the Taguchi method showed that the yield increased to $40 \%$ (1.28 g/l). Recent studies have also shown that the molecular weight of hybrid proteins increases by $34 \mathrm{kD}$ compared to the native protein, but it has no negative effect on protein expression. On the other hand, INTthiol induction demonstrated suitable $\mathrm{V}$ antigen purification (Fig. 5) and this strategy was used for large-scale production of proteins and INT self-cleavage can be performed at $4{ }^{\circ} \mathrm{C}$ without DTT. In summary, the pTX-V expression system can be used as a suitable substitute for the industrial production of vaccines against sub-units of plague.

Acknowledgements We would like to thank the research council of Malek-Ashtar University of Technology for the financial support of this investigation.

\section{Compliance with Ethical Standards}

Conflict of interest The authors declare no conflict of interest. 


\section{References}

1. Wren, B. W. (2003). The Yersiniae: A model genus to study the rapid evolution of bacterial pathogens. Nature Reviews Microbiology, 1(1), 55-64.

2. Perry, R. D., \& Fetherston, J. D. (1997). Yersinia pestis-Etiologic agent of plague. Clinical Microbiology Reviews, 10(1), 35-66.

3. Parkhill, J., Wren, B. W., Thomson, N. R., Titball, R. W., et al. (2001). Genome sequence of Yersinia pestis, the causative agent of plague. Nature, 413(6855), 523-527.

4. Titball, R. W., \& Williamson, E. D. (2001). Vaccination against bubonic and pneumonic plague. Vaccine, 19(30), 4175-4184.

5. Verma, S. K., \& Tuteja, U. (2016). Plague vaccine development: Current research and future trends. Frontiers in Immunology, 7, 602 .

6. Feodorova, V. A., \& Motin, V. L. (2012). Plague vaccines: Current developments and future perspectives. Emerging Microbes \& Infections, 1 , e36.

7. Rai, R., Das, B., Choudhary, N., Talukdar, A., \& Rao, D. N. (2015). MAP of F1 and V antigens from Yersinia pestis astride innate and adaptive immune response. Microbial Pathogenesis, 87, 13-20.

8. Oyerheim, K. A., Depaolo, R. W., Debord, K. L., Morrin, E. M., Anderson, D. M., et al. (2005). LcrV plague vaccine with altered immunomodulatory properties. Infection and Immunity, 73(8), $5152-5159$.

9. Carr, S., Miller, J., Leary, S. E., Am, B., Ho, A., \& Williamson, E. D. (1999). Expression of a recombinant form of the $V$ antigen of Yersinia pestis, using three different expression systems. Vaccine, 18(1-2), 153-159.

10. Anderson, G. W., Leary, S. E., Williamson, E. D., Titball, R. W., Welkos, S. L., Worsham, P. L., et al. (1996). Recombinant V antigen protects mice against pneumonic and bubonic plague caused by F1-capsule-positive and -negative strains of Yersinia pestis. Infection and Immunity, 64(11), 4580-4585.

11. Chong, S., Shao, Y., Paulus, H., Benner, J., Perler, F. B., \& Xu, M. Q. (1996). Protein splicing involving the Saccharomyces cerevisiae VMA iIntein: The steps in the splicing pathway, side reactions leading to protein cleavage, and establishment of an in vitro splicing system. Journal of Biological Chemistry, 271(36), 22159-22168

12. Anraku, Y., Mizutani, R., \& Satow, Y. (2005). Protein splicing: its discovery and structural insight into novel chemical mechanisms. IUBMB Life, 57(8), 563-574.

13. Gogarten, J. P., Senejani, A. G., Zhaxybayeya, O., Olendzenski, L., \& Hilario, E. (2002). Inteins: Structure, function, and evolution. Annual Review of Microbiology, 56(1), 263-287.

14. Pezza, J. A., Allen, K. N., \& Tolan, D. R. (2004). Intein-mediated purification of a recombinantly expressed peptide. Chemical Communications, 21, 2412-2413.

15. Chong, S., Mersha, F. B., Comb, D. G., Scott, M. E., Landry, D., et al. (1997). Single-column purification of free recombinant proteins using a self-cleavable affinity tag derived from a protein splicing element. Gene, 192(2), 271-281.

16. Wood, D. W., Wu, W., Nelfort, G., Derbyshire, V., \& Belfort, M. (1999). A genetic system yields self-cleaving inteins for bioseparations. Nature Biotechnology, 17(9), 889-892.

17. Banki, M. R., \& Wood, D. W. (2005). Inteins and affinity resin substitutes for protein purification and scale up. Microbial Cell Factories, 4, 32.

18. Terpe, K. (2003). Overview of tag protein fusions: From molecular and biochemical fundamentals to commercial systems. Applied Microbiology and Biotechnology, 60(5), 523-533.

19. Chong, S., Montello, G. E., Zhang, A., Cantor, E. J., Liao, W., et al. (1998). Utilizing the C-terminal cleavage activity of a protein splicing element to purify recombinant proteins in a single chromatographic step. Nucleic Acid Research, 26(22), 5109-5115.

20. Evans, T. C., Benner, J., \& Xu, M. Q. (1999). The Cyclization and polymerization of bacterially expressed proteins using modified self-splicing inteins. Journal of Biological Chemistry, 274(26), 18359-18363.

21. Rao, R. S., Kumar, C. G., Prakasham, R. S., \& Hobbs, P. J. (2008). The Taguchi methodology as a statistical tool for biotechnological applications: A critical appraisal. Biotechnology Journal, 3(4), 510-523.

22. Roy, R. K. (1990). A primer on the Taguchi method. Dearborn, MI: Society of Manufacturing Engineers, Michigan.

23. Prasad, K. K., Mohan, S. V., Rao, R. S., Pati, B. R., \& Sarma, P. N. (2005). Laccase production by Pleurotusostreatus 1804: Optimization of submerged culture conditions by Taguchi DOE methodology. Biochemical Engineering Journal, 24(1), 17-26.

24. Muhammad, S. A., Ahmed, S., Ismail, T., \& Hameed, A. (2014). Taguchi's experimental design for optimizing the production of novel thermostable polypeptide antibiotic from Geobacillus pallidus SAT4. Pakistan Journal of Pharmaceutical Sciences, 27(1), 11-23.

25. Ranjbari, J., Babaeipour, V., Vahidi, H., Moghimi, H., Mofid, M. R., \& Namvaran, M. M. (2015). Enhanced production of insulin-like growth factor I Protein in Escherichia coli by optimization of five key factors. Iranian Journal of Pharmaceutical Research, 14(3), 907-917.

26. Cornelis, G. R. (2000). Molecular and cell biology aspects of plague. Proceedings of the National Academy of Sciences USA, 97(16), 8778-8783.

27. Titball, R. W., \& Williamson, E. D. (2004). Yersinia pestis (plague) vaccines. Expert Opinion on Biological Therapy, 4(6), 965-973.

28. Sun, W., Roland, K. L., \& Curtiss, R. (2011). Developing live vaccines against Yersinia pestis. Journal of Infection in Developing Countries, 5(9), 614-627.

29. Esposito, D., \& Chatterjee, D. K. (2006). Enhancement of soluble protein expression through the use of fusion tags. Current Opinion in Biotechnology, 17(4), 353-358.

30. Sharma, S. S., Chong, S., \& Harcum, S. W. (2006). Inteinmediated protein purification of fusion proteins expressed under high-cell density conditions in E. coli. Journal of Biotechnology, 125(1), 48-56.

31. Crowe, J., Dobeli, H., Gentz, R., Hochuli, E., Stuber, D., \& Henco, K. (1994). 6xHis-Ni-NTA chromatography as a superior technique in recombinant protein expression/purification. Methods in Molecular Biology, 31, 371-387.

32. Seyfi, R., Babaeipour, V., Mofid, M. R., \& Kahaki, F. A. (2019). Expression and production of recombinant scorpine as a potassium channel blocker protein in Escherichia coli. Biotechnology and Applied Biochemistry, 66(1), 119-129.

33. LaVallie, E. R., \& McCoy, J. M. (1995). Gene fusion expression systems in Escherichia coli. Current Opinion in Biotechnology, 6(5), 501-506.

34. Hosseini, E. S., Zeinoddini, M., Kashani, H. H., \& Ghoddusi, A. (2012). Intein as a novel strategy for protein purification. Life Sci J, 4, 9 .

35. Hosseini, S., Zeinoddini, M., Fallah, J., \& Saeedinia, A. R. (2015). Cloning and expression of aequorin photoprotein using intein tag. ISMJ, 17(6), 1168-1175.

36. Seyed Hosseini, E., Moniri, R., Goli, Y. D., \& Kashani, H. H. (2016). Purification of antibacterial CHAP K protein using a self-cleaving fusion tag and its activity against methicillinresistant Staphylococcus aureus. Probiotics and Antimicrobial Proteins, 8(4), 202-210. 
37. Fong, B. A., Wu, W. Y., \& Wood, D. W. (2010). The potential role of self-cleaving purification tags in commercial-scale processes. Trends in Biotechnology, 28(5), 272-279.

38. Wood, D. W. (2014). New trends and affinity tag designs for recombinant protein purification. Current Opinion in Structural Biology, 26, 54-61.

39. Leary, S. E. C., Williamson, E. D., Griffin, K. F., Russell, P., Eley, S. M., \& Titball, R. W. (1995). Active immunisation with recombinant $\mathrm{V}$ antigen from Yersinia pestis protects mice against plague. Infection and Immunity, 63, 2854-2858.
40. Carr, S., Miller, J., Leary, S. E. C., Bennett, A. M., Ho, A., \& Williamson, E. D. (2000). Expression of a recombinant from of the $\mathrm{V}$ antigen of Yersinia pestis, using three different expression systems. Vaccine, 18, 153-159.

Publisher's Note Springer Nature remains neutral with regard to jurisdictional claims in published maps and institutional affiliations. 